Article

\title{
Examination of Surface Temperature Modification by Open-Top Chambers along Moisture and Latitudinal Gradients in Arctic Alaska Using Thermal Infrared Photography
}

\author{
Nathan C. Healey ${ }^{1, *}$, Steven F. Oberbauer ${ }^{2}$ and Robert D. Hollister ${ }^{3}$ \\ Received: 25 July 2015; Accepted: 30 December 2015; Published: 11 January 2016 \\ Academic Editors: Santonu Goswami, Janet Elizabeth Nichol, Richard Gloaguen and Prasad S. Thenkabail \\ 1 NASA Jet Propulsion Laboratory, California Institute of Technology, 4800 Oak Grove Dr., Pasadena, \\ CA 91109 , USA \\ 2 Department of Biological Sciences, Florida International University, 11200 SW 8th St., Miami, FL 33199, USA; \\ oberbaue@fiu.edu \\ 3 Department of Biological Sciences, Grand Valley State University, 212 Henry Hall, 1 Campus Dr., Allendale, \\ MI 49401, USA; hollistr@gvsu.edu \\ * Correspondence: nhealey@jpl.nasa.gov; Tel.: +1-818-393-5358; Fax: +1-818-354-0988
}

\begin{abstract}
Passive warming manipulation methodologies, such as open-top chambers (OTCs), are a meaningful approach for interpretation of impacts of climate change on the Arctic tundra biome. The magnitude of OTC warming has been studied extensively, revealing an average plot-level warming of air temperature that ranges between 1 and $3{ }^{\circ} \mathrm{C}$ as measured by shielded resistive sensors or thermocouples. Studies have also shown that the amount of OTC warming depends in part on location climate, vegetation, and soil properties. While digital infrared thermometers have been employed in a few comparisons, most of the focus of the effectiveness of OTC warming has been on air or soil temperature rather than tissue or surface temperatures, which directly translate to metabolism. Here we used thermal infrared (TIR) photography to quantify tissue and surface temperatures and their spatial variability at a previously unavailable resolution $\left(3-6 \mathrm{~mm}^{2}\right)$. We analyzed plots at three locations that are part of the International Tundra Experiment (ITEX)-Arctic Observing Network (AON-ITEX) network along both moisture and latitudinal gradients spanning from the High Arctic (Barrow, AK, USA) to the Low Arctic (Toolik Lake, AK, USA). Our results show a range of OTC surface warming from 2.65 to $1.27^{\circ} \mathrm{C}(31 \%-10 \%)$ at our three sites. The magnitude of surface warming detected by TIR imagery in this study was comparable to increases in air temperatures previously reported for these sites. However, the thermal images revealed wide ranges of surface temperatures within the OTCs, with some surfaces well above ambient unevenly distributed within the plots under sunny conditions. We note that analyzing radiometric temperature may be an alternative for future studies that examine data acquired at the same time of day from sites that are in close geographic proximity to avoid the requirement of emissivity or atmospheric correction for validation of results. We foresee future studies using TIR photography to describe species-level thermodynamics that could prove highly valuable toward a better understanding of species-specific responses to climate change in the Arctic.
\end{abstract}

Keywords: remote sensing; thermal imagery; open-top chamber; Arctic; Alaska

\section{Introduction}

Understanding the impacts of climate change on Arctic vegetation is a key requirement for prediction of how Arctic ecosystems will respond to future conditions [1]. Passive warming 
manipulation methodologies, such as hexagonal open-top chambers (OTCs), that simulate future scenarios of warming on small plots $\left(\sim 1 \mathrm{~m}^{2}\right)$ have been extensively investigated in the Arctic [1-7]. Previous warming studies using OTCs have been directed toward analyzing specific species responses [8], radiation dynamics [9], plant phenology [10], snow regime shifts [11], and trace gas exchange $[12,13]$ to name a few. Studies have spanned multiple locations to include gradients; DeFrenne et al. [5,6] examined transplants of forest understory species along a latitudinal gradient, and Oberbauer et al. [13] studied ecosystem $\mathrm{CO}_{2}$ fluxes in response to latitudinal and moisture gradients. Meta-analyses of many sites combined have quantified the impacts of passive warming treatments on tundra vegetation and indicate a warming climate in high latitudes and high elevations is changing plant communities and ecosystem function [14,15]. A key variable in the interpretation of the treatment responses is the effectiveness of the OTC experimental warming within the different climate regimes, vegetation types, and soil microclimates of the tundra biome.

The increase in mean air temperatures within OTCs ranges from 1 to $3^{\circ} \mathrm{C}$ and is dependent on size and design, site climate, ecosystem type, and soil properties [3,4,16-22]. Soil temperatures at depth have been regularly tested in OTCs, but generally do not show a significant increase [23,24], although surface temperatures do [22]. Most of the research has focused on air temperatures measured by shielded resistive sensors or thermocouples rather than tissue or surface temperatures, but the measurements have been limited to just a few locations per plot. Considerable emphasis has been placed on documenting gradients in air temperature within OTCs by measuring air temperature at specific positions. However, what determines metabolic rates are tissue and surface temperatures. Tissue surface temperatures are determined to a large degree by radiation loads, boundary layer, and evapotranspiraton rates, whereas air temperature is driven by sensible heat [22]. Some measurements have been made with digital infrared thermometers in OTCs, but the resolution is limited. Given the small size of most OTCs, that they trap heat by increasing the boundary layer, and that they slightly reduce the light available to plants inside, detailed comparisons of the surface temperatures of vascular plants, moss, lichens, litter, and soil in and out of OTCs would be highly desirable.

Recent advances in thermal infrared photography (TIR) have made possible fine-scale, calibrated surface temperature measurement at resolutions previously unattainable with digital infrared thermometers. The objective of this study was to quantify the range and spatial variation in temperatures of tundra surfaces (vascular and non vascular plants, lichens, litter, and soil) induced by the presence of OTCs installed along moisture and latitudinal gradients in Arctic Alaska, USA.

\section{Materials and Methods}

The locations used for this research were situated along a gradient from High to Low Arctic (Figure 1) including: Barrow $\left(71^{\circ} 18^{\prime} \mathrm{N}, 156^{\circ} 40^{\prime} \mathrm{W} ; 7\right.$ masl), Atqasuk $\left(70^{\circ} 29^{\prime} \mathrm{N}, 157^{\circ} 25^{\prime} \mathrm{W} ; 21\right.$ masl), and Toolik Lake, Alaska $\left(68^{\circ} 37^{\prime} \mathrm{N}, 149^{\circ} 36^{\prime} \mathrm{W} ; 736\right.$ masl). All of these locations are part of the International Tundra Experiment (ITEX) and the Arctic Observatory Network (AON-ITEX). Data for this project are archived at the ACADIS data repository [25]. The OTCs used in this study for passive warming treatments were hexagonal in shape $(\sim 1 \mathrm{~m}$ in diameter, $\sim 0.5 \mathrm{~m}$ in height) with an open top allowing for ventilation and precipitation inputs. They were constructed using $1.0 \mathrm{~mm}$ thick walls of Sun-Lite ${ }^{\circledR}$ HP fiberglass glazing (Kalwall Corporation, Manchester, NH, USA) that have high solar transmittance in visible wavelengths $(\sim 86 \%)$ and low transmittance in longwave (thermal) wavelengths $(\sim 5 \%)$. The walls of the chambers are inwardly-inclined $\left(60^{\circ}\right.$ with respect to the horizontal) to trap heat. Each location has had OTCs deployed in representative plant communities at two points on the local soil moisture spectrum (wet/moist and dry) since the mid 1990s. Occurrence of plant growth forms and surface features in the plots was recorded using point-intercept methods $\left(0.75 \mathrm{~m}^{2}\right.$ area with 100 grid points [17]). Percent cover of major surface feature types for each site and moisture regime are presented in Figure 2. Detailed site information is presented below. 


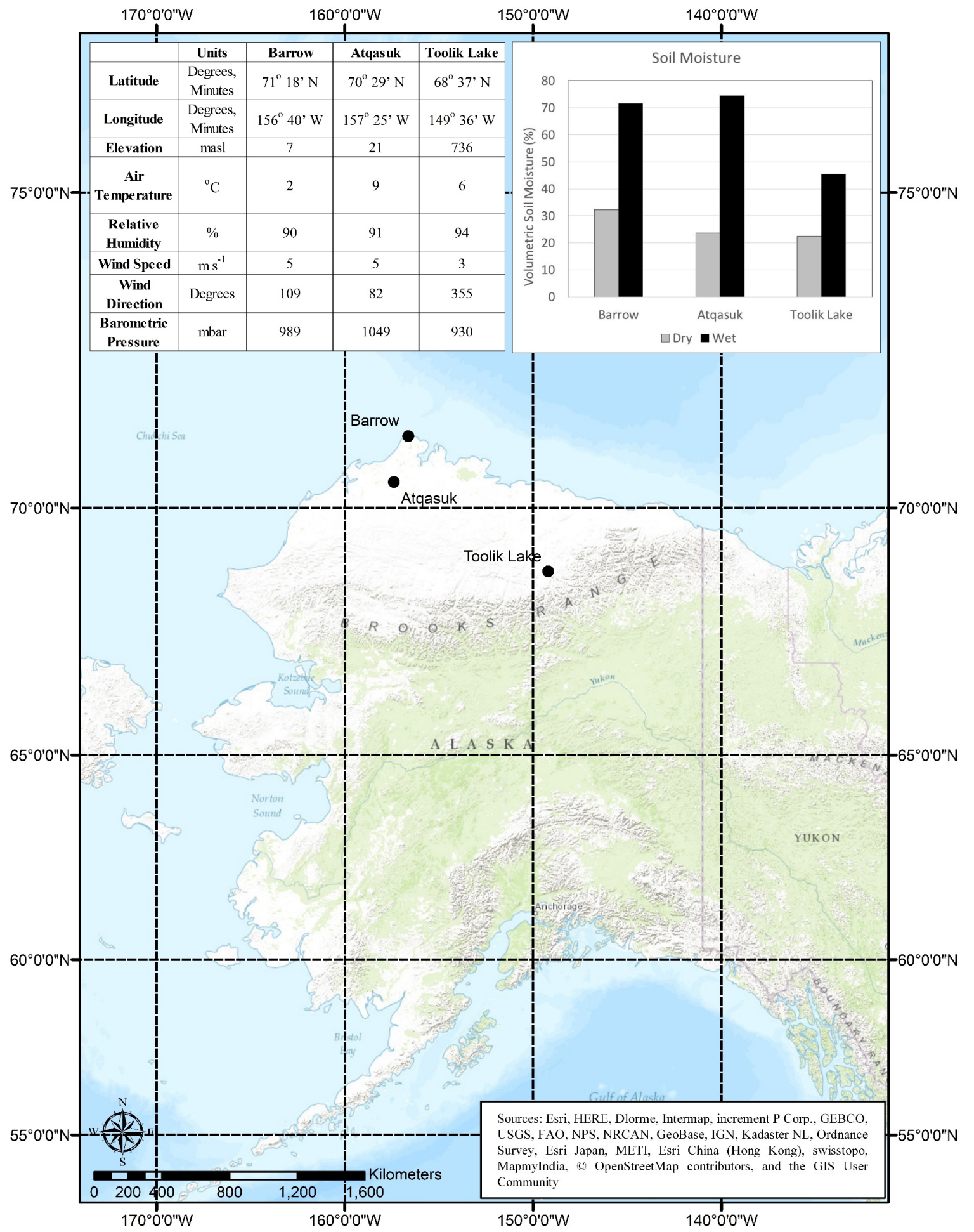

Figure 1. Map of the three locations used in this study along with weather data during image acquisition. Soil moisture measurements recorded within three days of image acquisition are from plots along the ITEX transects immediately adjacent to the study sites as described in Healey et al. [26] that represent the wet/moist and dry ITEX OTC/Control plots.

The Barrow wet site is located on the edge of a thaw lake basin and is dominated by graminoids, in particular Carex aquatilis [4]. Soils are organic (Histic Pergelic Cryaquepts) with shallow depth of thaw. As a result, standing water is frequently present at the wet site. The vegetation at the Barrow 
dry site is dominated by a dwarf deciduous shrub, Salix rotundifolia, with evergreen shrubs (e.g., Cassiope tetragona) and graminoids (e.g., Luzula spp., Arctagrostis latifolia). Soils at the Barrow dry site are mostly mineral Pergelic Cryaquepts on silt, sand, and gravel on a raised beach ridge [4].

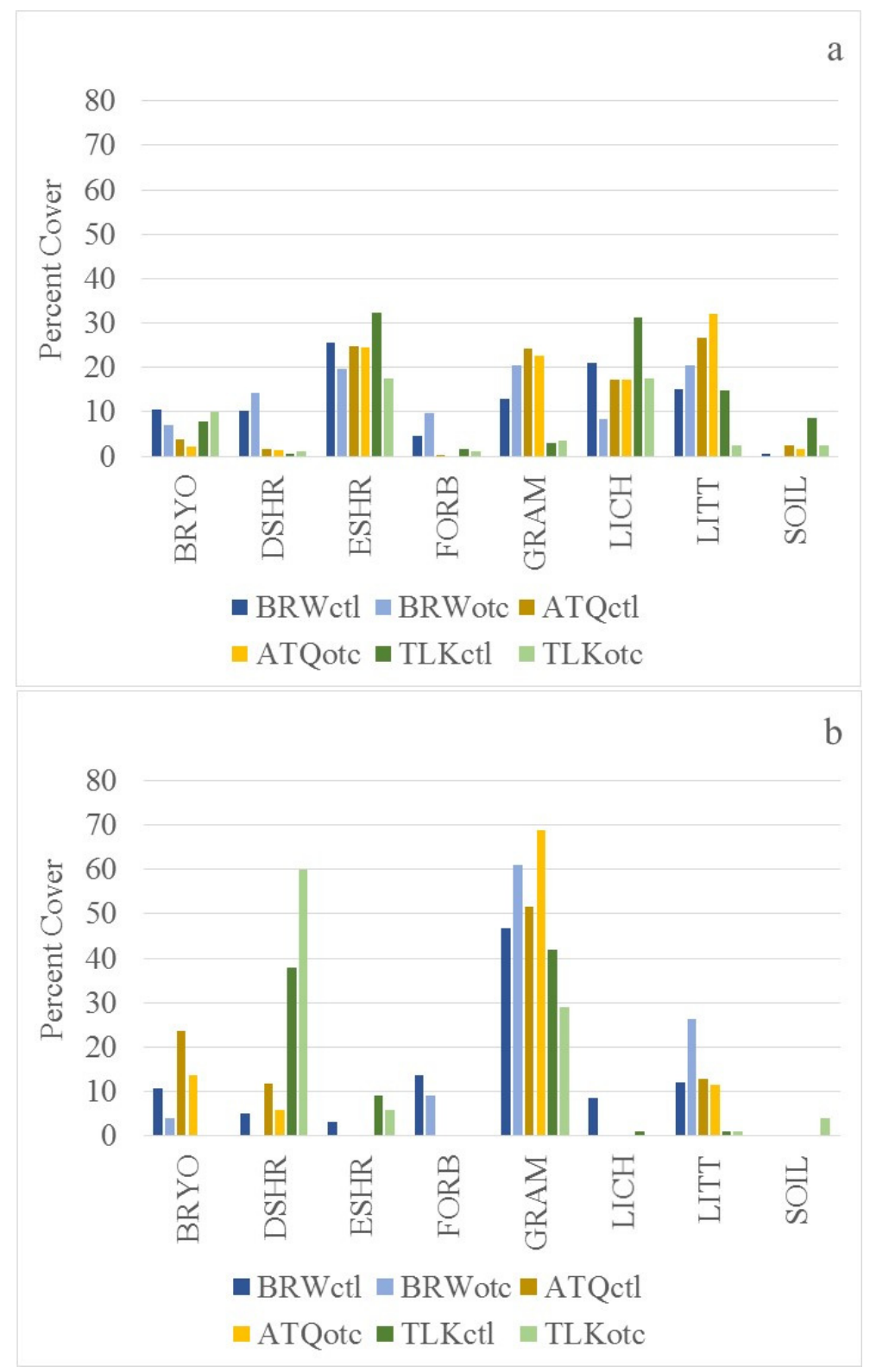

Figure 2. Aggregate percent cover of major plant growth forms and surface features at each site $(\mathrm{BRW}=$ Barrow $; \mathrm{ATQ}=$ Atqasuk, $\mathrm{TLK}=$ Toolik Lake) for dry (a) and wet/moist (b) moisture regimes $(\mathrm{ctl}=$ control, otc $=$ open top chamber). Note: cover data were not available for all plots at Toolik Lake [25].

The wet meadow at Atqasuk is located on the edge of a thaw lake basin and is dominated by Carex aquatilis [4]. Standing water is present throughout most of the summers in this site. Soils at the wet site are Histic Pergelic Cryaquepts. Soils at the dry site are Pergelic Cryopsamments on aolian sand of a stabilized sand dune. Vegetation at the dry site is dominated by the dwarf evergreen shrubs Ledum palustre, Cassiope tetragona, and Vaccinium vitis-idaea and the graminoids Hierochloe alpina and Luzula confusa [4]. 
At Toolik, the OTCs are placed on moist tussock tundra rather than wet sedge tundra because of the great abundance of tussock tundra in the region around Toolik Lake and the relative rarity of wet sedge vegetation. Tussock tundra at Toolik is dominated by the graminoids Eriophorum vaginatum and Carex bigelowii, the deciduous shrubs Betula nana and Salix pulchra, and the dwarf evergreen shrubs Ledum palustre and Vaccinium vitis-idaea [11]. Eriophorum vaginatum, the dominant plant at the site, is a sedge that forms tussocks or raised mounds with the current year's growth, persisting on top of the previous year's growth. Soils are Pergelic Cryaquepts with thaw depths attaining 50-60 cm. Standing water is rarely present at the site except during snowmelt. The dry site vegetation is dry heath dominated by Dryas octopetala, Salix phlebophylla, Arctous alpina, and fruticose lichens [11,21] located on well-drained rocky Pergelic Cryumbrepts. Thaw depth may attain $1 \mathrm{~m}$ or more.

The timing of this study was designed to analyze thermal properties of vegetation and uncovered soil/moss during peak growth in the Arctic growing season (late July-early August). Thermal infrared photographs were collected from a stable platform/tripod once at midday ( 12:00-14:00 AST) from a height of 2.5-3.0 m between 4 and 6 August 2014 (Barrow: 4 August, Atqasuk and Toolik Lake: 6 August) at four randomly selected control plots and four coinciding OTCs within two different moisture regimes at each study location (wet/moist and dry: 24 plots overall). Imagery was collected at midday to minimize any shading effects from the OTC walls. Multiple images of each target were acquired to quantify measurement bias and ensure data integrity was upheld (i.e., maintain nadir angle and ensure camera focus). At Barrow and Toolik Lake we used FLIR A655sc cameras (FLIR Systems, Wilsonville, OR, USA) which have an uncooled microbolometer detector equipped with a $13.1 \mathrm{~mm}$ lens exhibiting a $45^{\circ}$ field of view, a spatial resolution of roughly $3 \mathrm{~mm}(640 \times 480$ : over 300,000 pixels per image), and a spectral range of 7.5-14 $\mu \mathrm{m}$. At Atqasuk, we used a FLIR A325sc camera which has an uncooled microbolometer detector equipped with a $10 \mathrm{~mm}$ lens exhibiting a $45^{\circ}$ field of view, a spatial resolution of roughly $6 \mathrm{~mm}(320 \times 240$ : over 76,000 pixels per image-not resampled to the A655sc resolution), and a spectral range of $7.5-13 \mu \mathrm{m}$. The thermal sensitivity of both camera models, defined by the Noise Equivalent Temperature Difference (NETD) is $0.03{ }^{\circ} \mathrm{C}$ at $30^{\circ} \mathrm{C}$. Accuracy of temperature measurements for the FLIR a655sc and a325sc cameras is $\pm 2 \%$ of the reading with an average bias of $\pm 0.104^{\circ} \mathrm{C}$. All images were atmospherically corrected via FLIR's Research IR Software with inputs of atmospheric temperature and humidity acquired from weather stations onsite, optic temperature (assumed to be equal to air temperature), and surface emissivity was set to 0.98 following the average emissivity between 7.5 and $14 \mu \mathrm{m}$ for tundra species reported in Wilber et al. [27]. Weather conditions for each day and location are presented in Map 1 and all sites experienced partly-mostly cloudy sky conditions on image dates. We calculated the average temperature of all pixels in each plot for each image, then consolidated the results for each treatment (wet/moist or dry) to examine differences within and among sites. To exclude non-uniform, microclimatic effects of the close proximity of the OTC to the vegetation around the inside perimeter of the structure, the OTC itself and the surface underlying the angled walls of the OTC were removed from image analysis to focus on the surface temperature of a circular area designated around the edge of the OTC opening that is visible from the nadir only (Figures 3-8). 


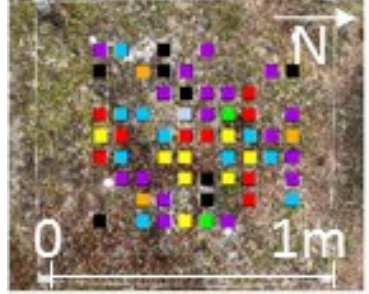

a

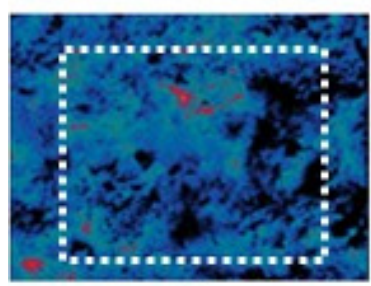

e

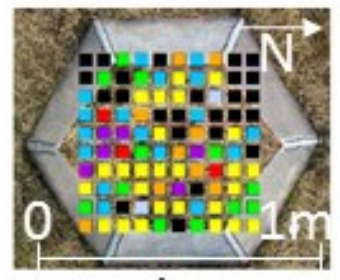

i

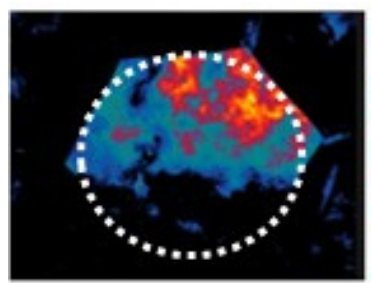

$\mathbf{m}$

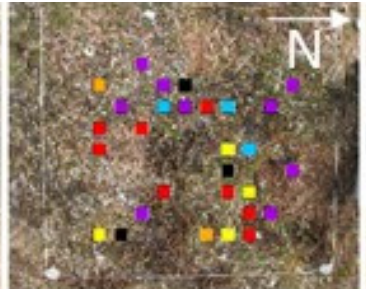

b

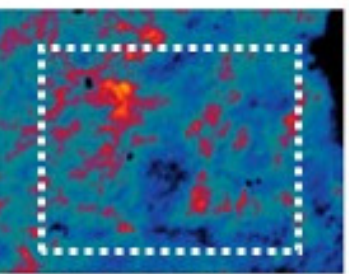

f
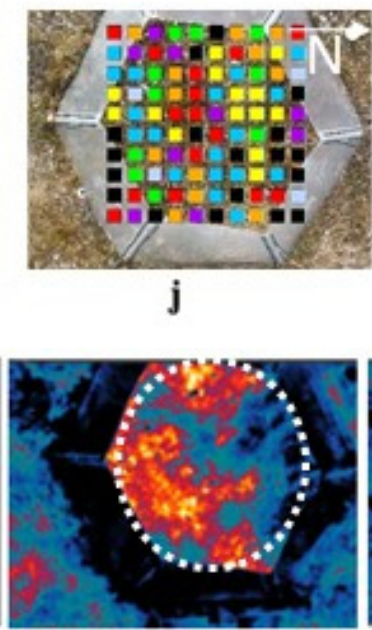

n

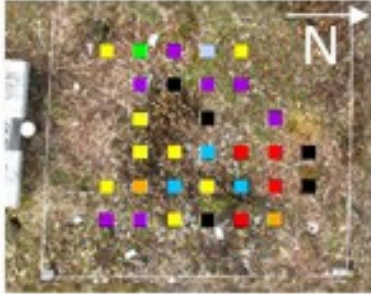

c

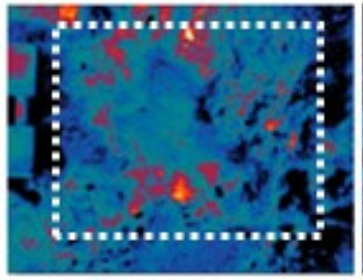

g

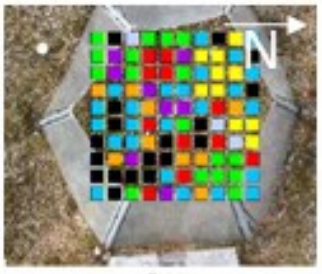

k

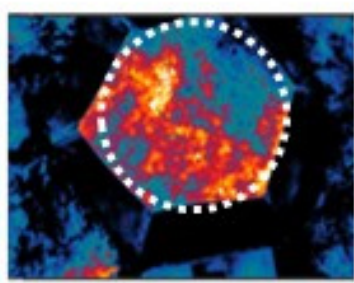

o

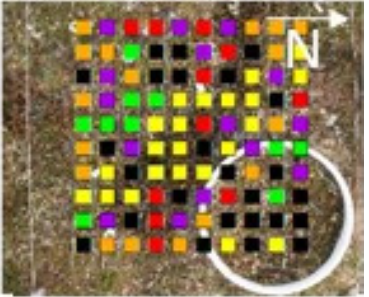

d

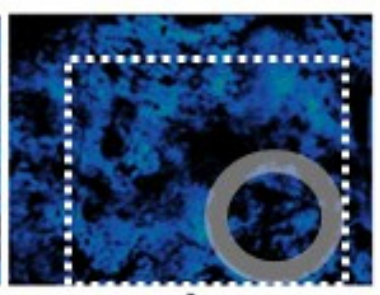

h

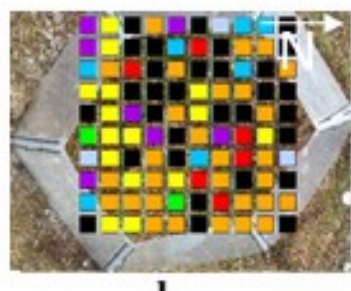

I

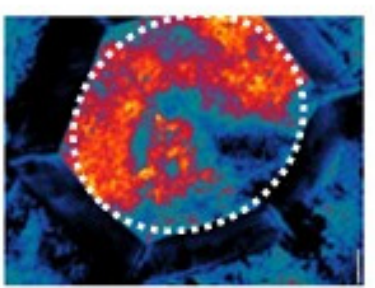

p

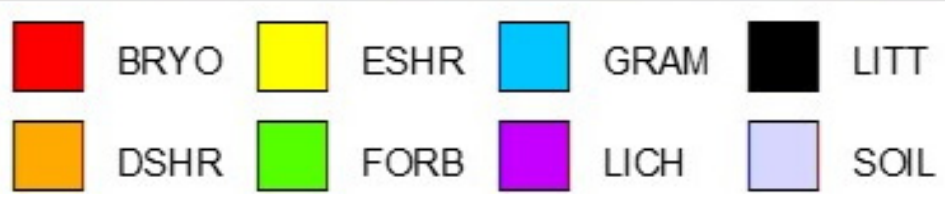

Figure 3. Images depicting four Barrow dry site plots (a-d) and the coinciding thermal images below $(\mathbf{e}-\mathbf{h})$; and images of four additional plots (i-1) with coinciding thermal images below $(\mathbf{m}-\mathbf{p})$. Note: the ring appearing in panels $(\mathbf{d}, \mathbf{h})$ is gas exchange collar not related to this study. Areas of image analysis are outlined with dotted white lines. Data within the transparent circular area has been removed. All temperatures are in degrees Celsius. Plant growth forms and surface features are depicted with the following abbreviations-BRYO: bryophyte/moss; DSHR: deciduous shrub; ESHR: evergreen shrub; FORB: forb; GRAM: graminoid; LICH: lichen; LITT: leaf litter; SOIL: bare soil/rock. 


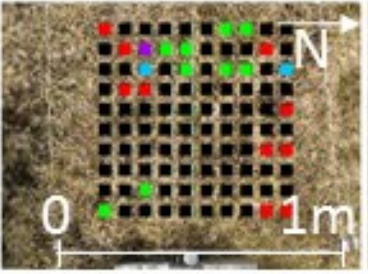

a

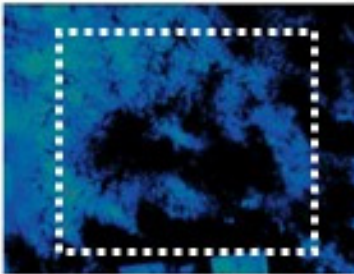

e

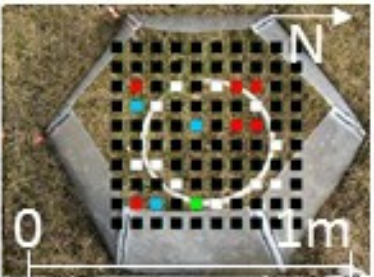

i

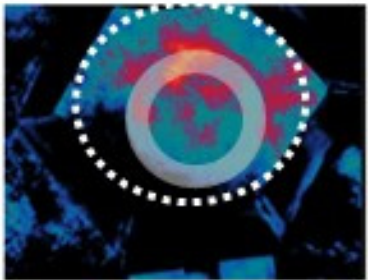

$\mathbf{m}$

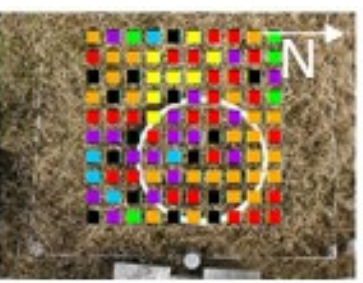

b

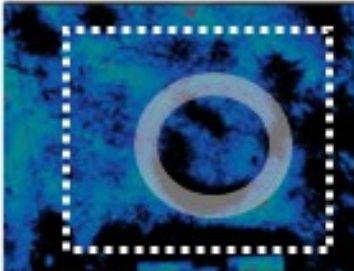

f

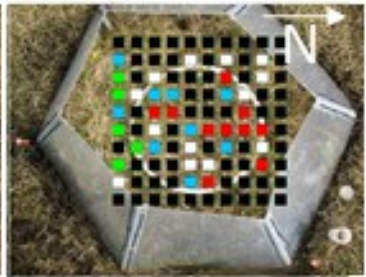

j

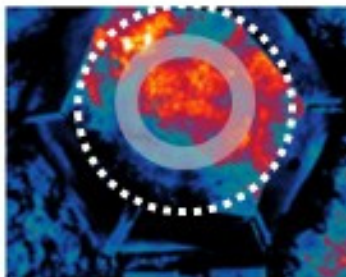

$\mathbf{n}$

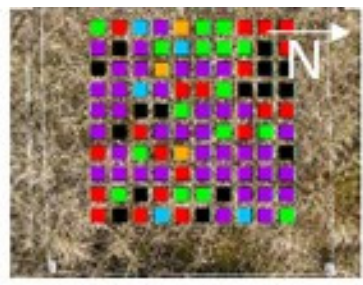

c

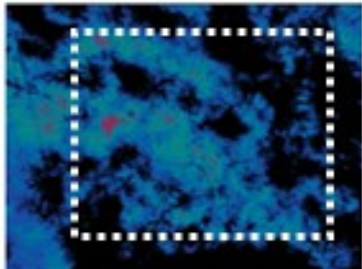

g

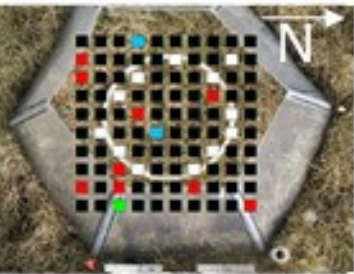

k

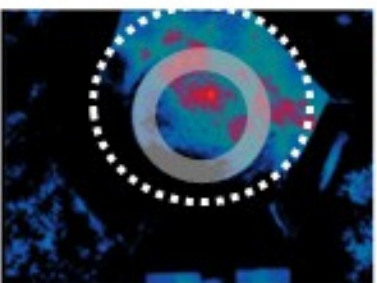

o

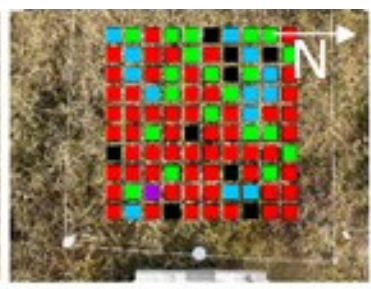

d

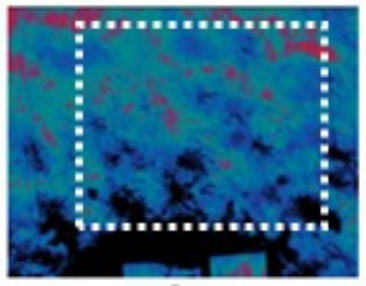

h

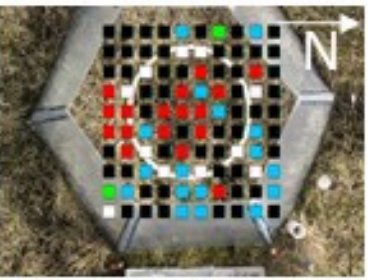

I

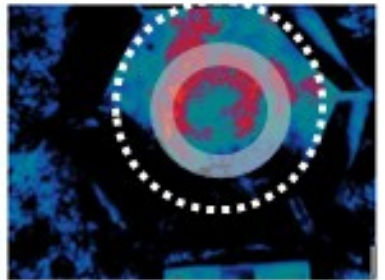

p

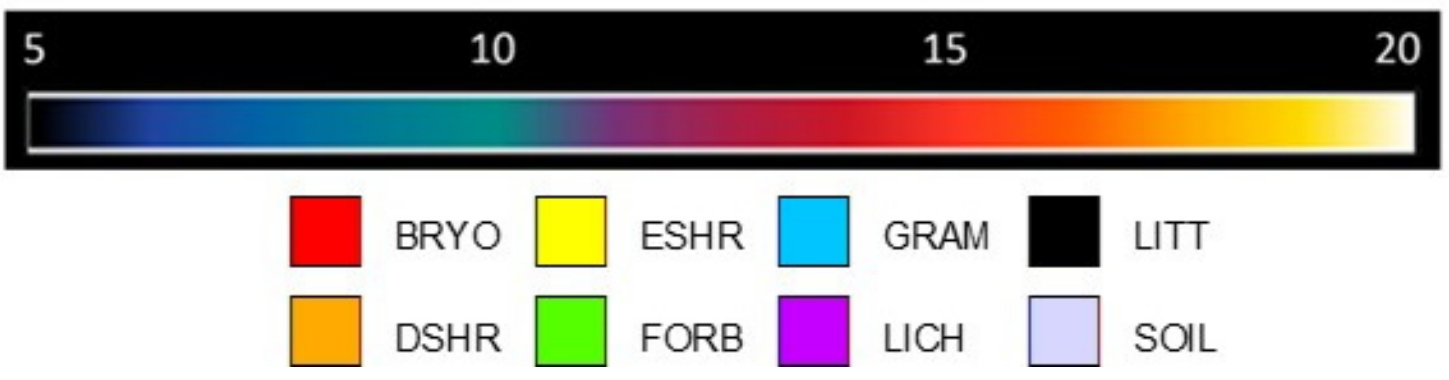

Figure 4. Images depicting four Barrow wet site plots (a-d) and the coinciding thermal images below (e-h); and images of four additional plots (i-1) with coinciding thermal images below $(\mathbf{m}-\mathbf{p})$. Note: the rings appearing in panels $(\mathbf{b}, \mathbf{f}, \mathbf{i}-\mathbf{p})$ are gas exchange collars not related to this study. Areas of image analysis are outlined with dotted white lines. Data in the transparent circular areas have been removed. All temperatures are in degrees Celsius. Plant growth forms and surface features are depicted with the following abbreviations-BRYO: bryophyte/moss; DSHR: deciduous shrub; ESHR: evergreen shrub; FORB: forb; GRAM: graminoid; LICH: lichen; LITT: leaf litter; SOIL: bare soil/rock. White grids symbolize chamber base points or plant identification tags. 


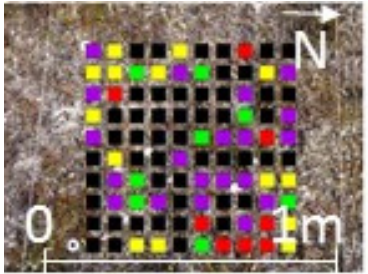

a

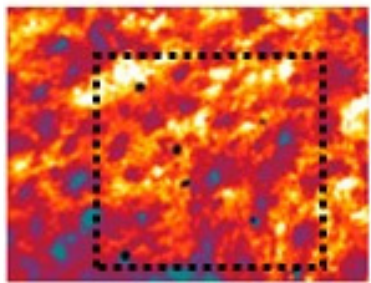

e
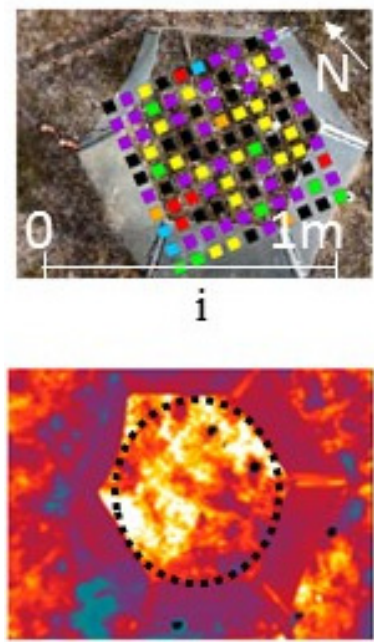

m

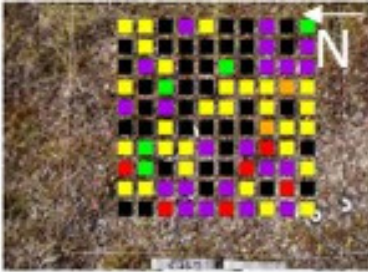

b

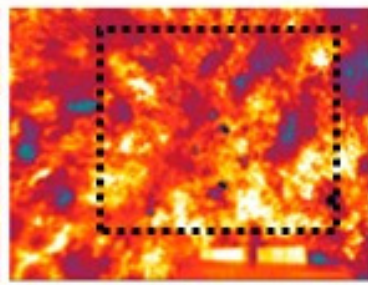

f

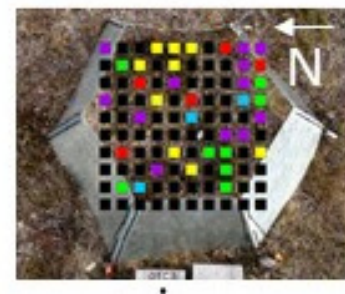

j

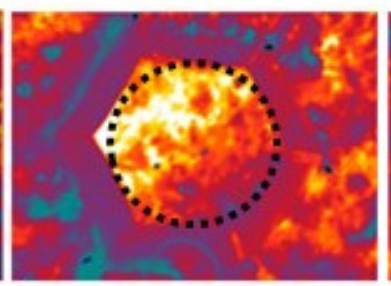

$\mathbf{n}$

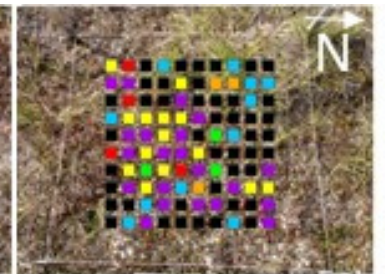

c

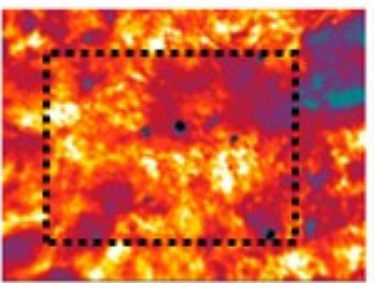

g

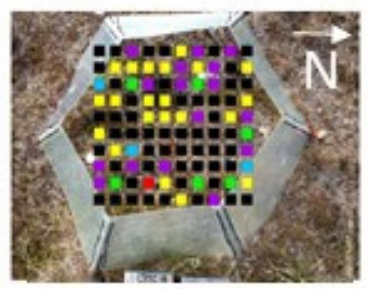

k

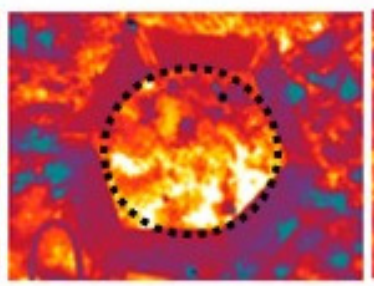

o

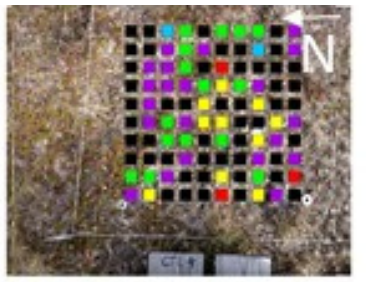

d

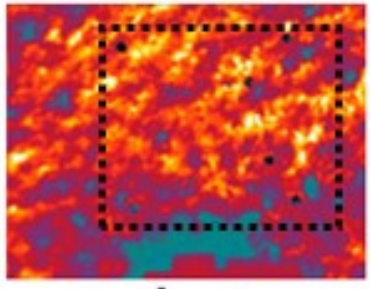

h

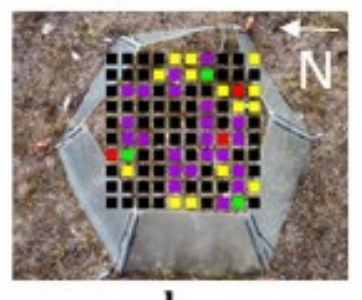

I

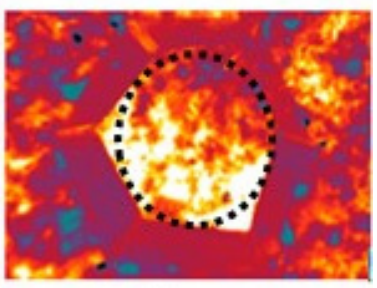

p

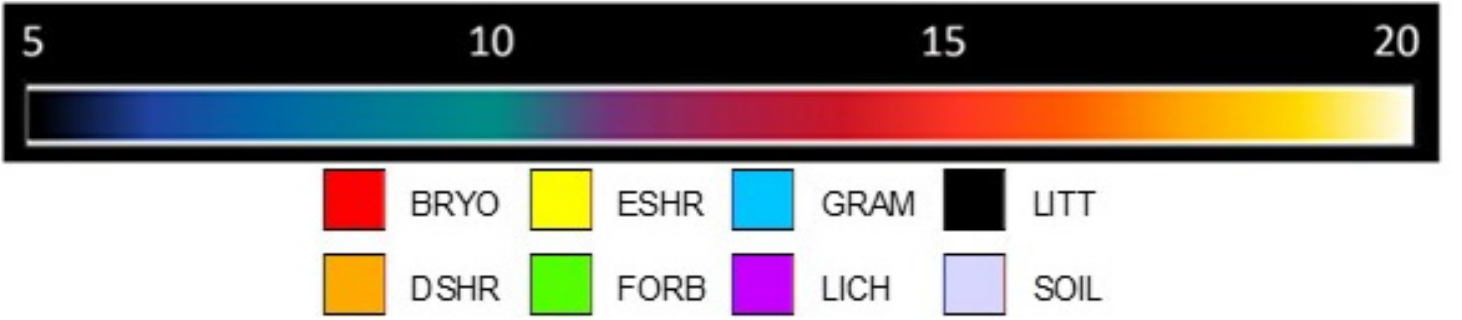

Figure 5. Images depicting four Atqasuk dry site plots (a-d) and the coinciding thermal images below (e-h); and images of four additional plots (i-1) with coinciding thermal images below $(\mathbf{m}-\mathbf{p})$. Areas of image analysis are outlined with dotted black lines. All temperatures are in degrees Celsius. Plant growth forms and surface features are depicted with the following abbreviations-BRYO: bryophyte/moss; DSHR: deciduous shrub; ESHR: evergreen shrub; FORB: forb; GRAM: graminoid; LICH: lichen; LITT: leaf litter; SOIL: bare soil/rock. 


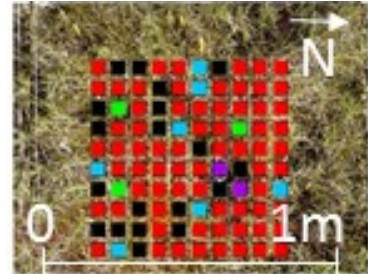

a

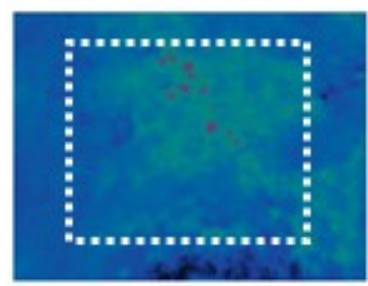

e

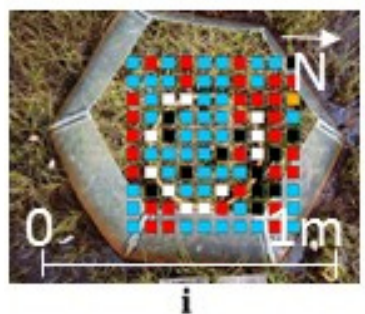

i

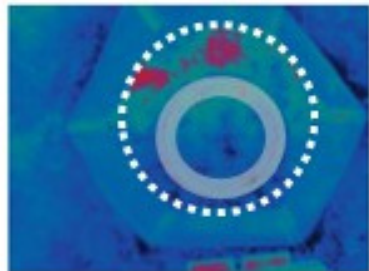

$\mathbf{m}$

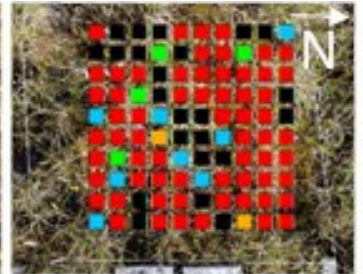

b

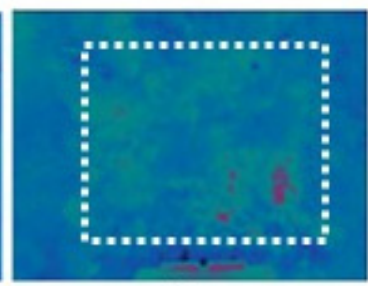

f

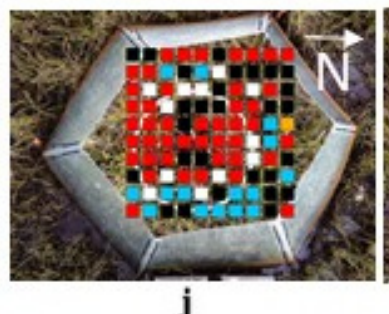

j

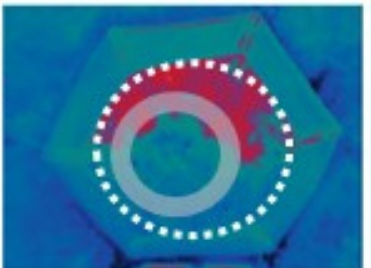

n

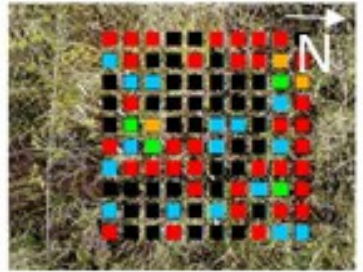

c

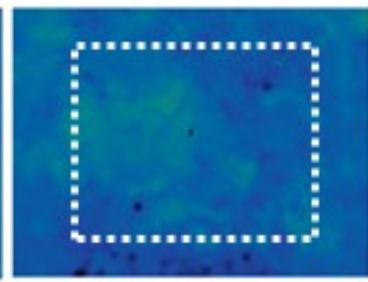

g

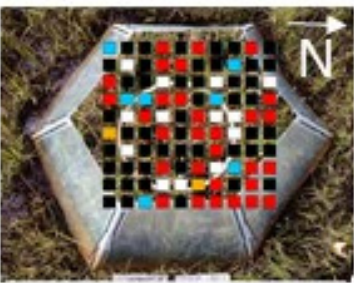

$\mathbf{k}$

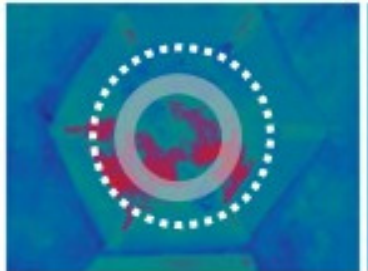

o

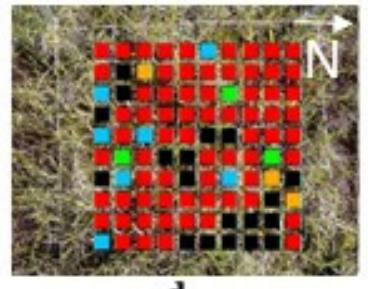

d

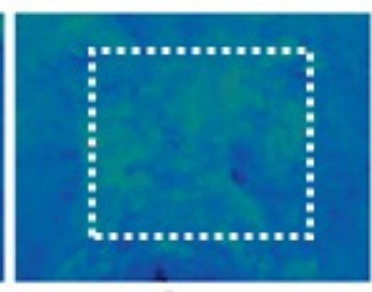

h
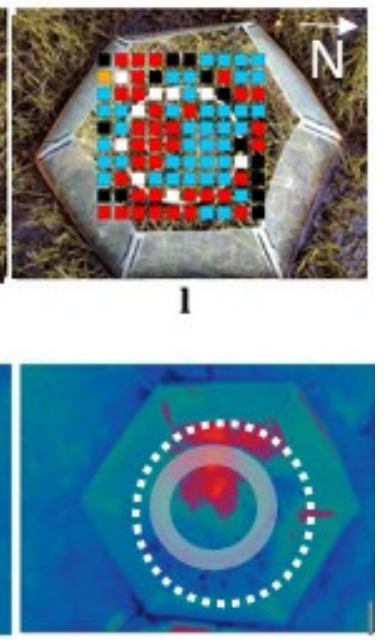

p
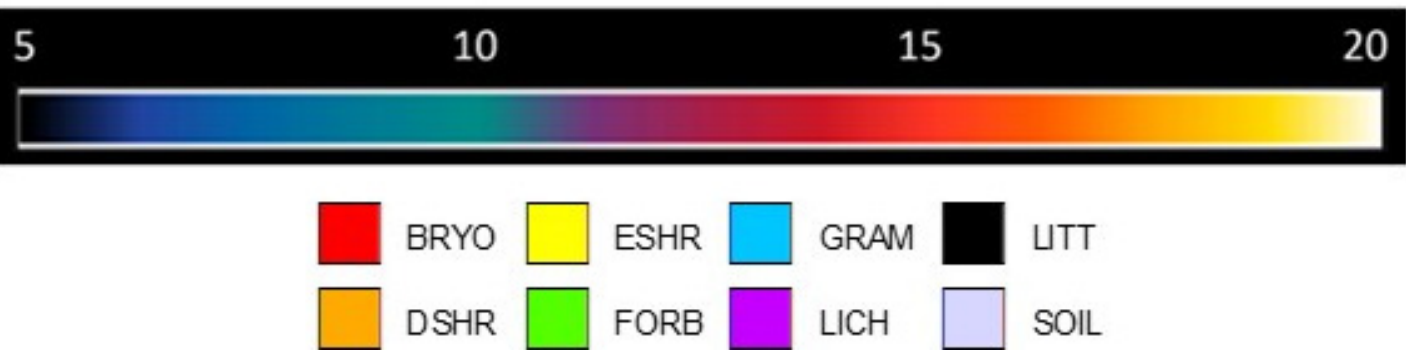

UTT

SOIL

Figure 6. Images depicting four Atqasuk wet site plots (a-d) and the coinciding thermal images below $(\mathbf{e}-\mathbf{h})$; and images of four additional plots (i-1) with coinciding thermal images below $(\mathbf{m}-\mathbf{p})$. Note: the rings appearing in panels $(\mathbf{i}-\mathbf{p})$ are gas exchange collars not related to this study. Areas of image analysis are outlined with dotted white lines. Data in the transparent circular areas have been removed. All temperatures are in degrees Celsius. Plant growth forms and surface features are depicted with the following abbreviations-BRYO: bryophyte/moss; DSHR: deciduous shrub; ESHR: evergreen shrub; FORB: forb; GRAM: graminoid; LICH: lichen; LITT: leaf litter; SOIL: bare soil/rock. White grids symbolize chamber base points or plant identification tags. 


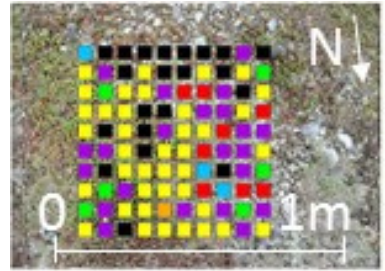

a

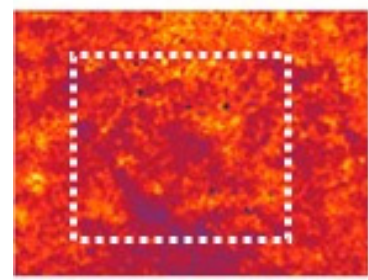

e
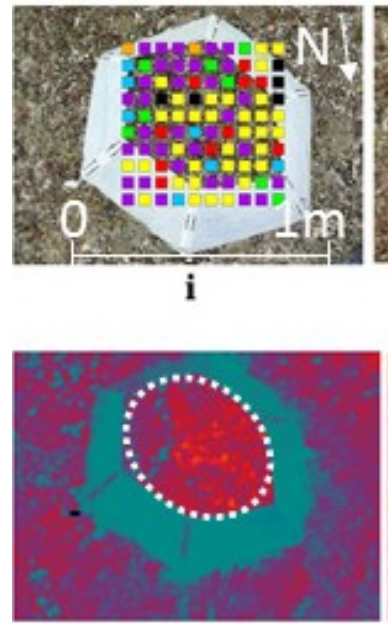

$\mathbf{m}$

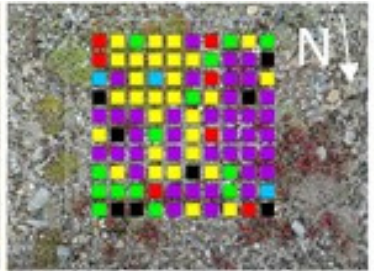

b

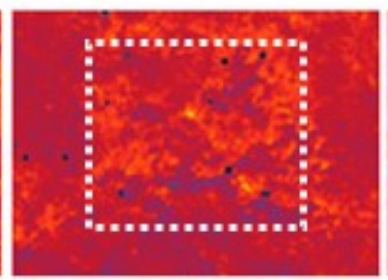

f
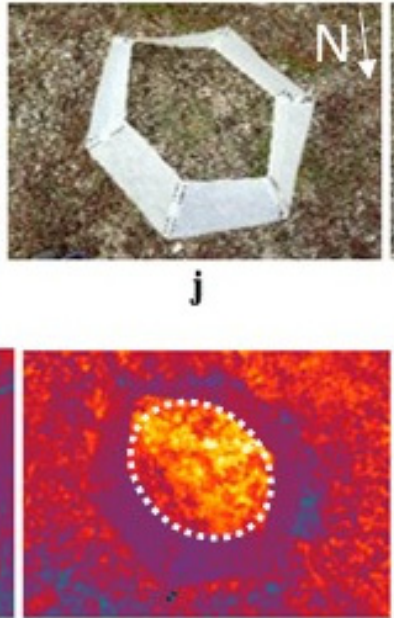

$\mathbf{n}$

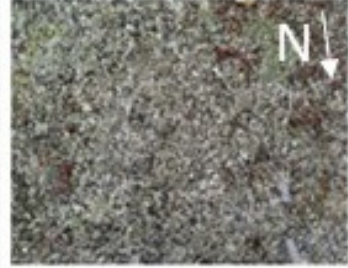

c

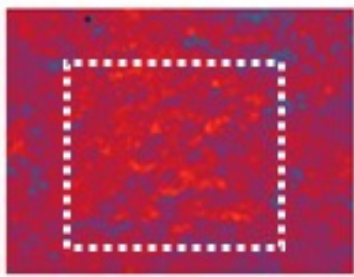

g

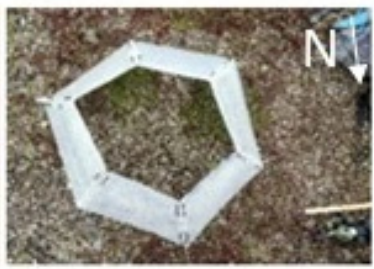

k

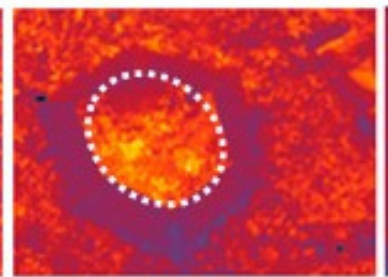

o

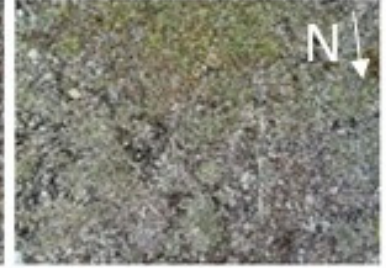

d

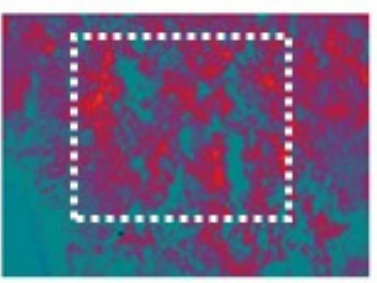

h
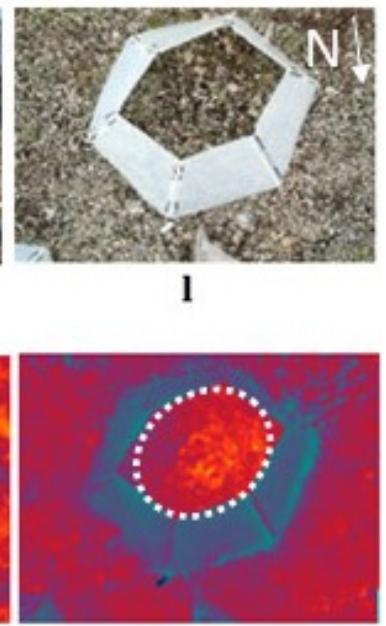

p
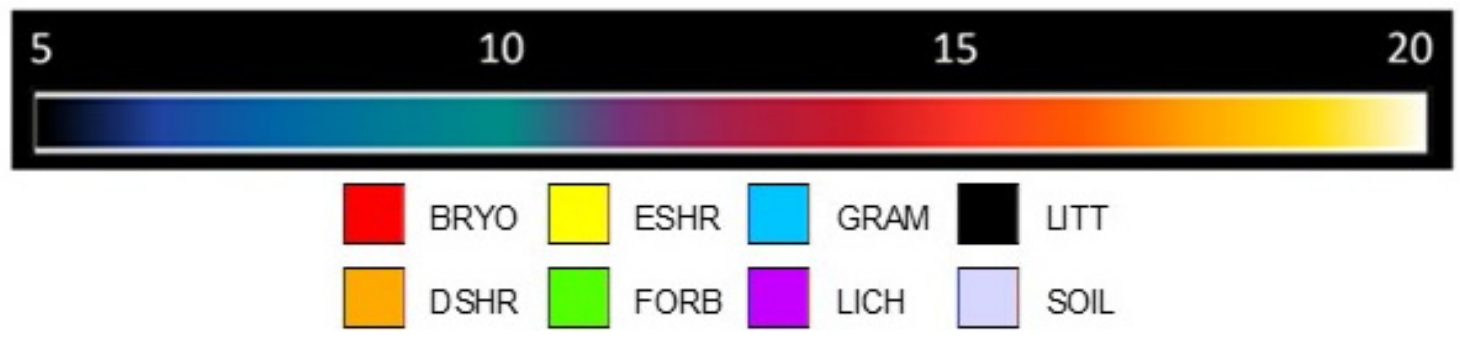

Figure 7. Images depicting four Toolik Lake dry site plots (a-d) and the coinciding thermal images below (e-h); and images of four additional plots (i-1) with coinciding thermal images below ( $\mathbf{m}-\mathbf{p})$. Areas of image analysis are outlined with dotted white lines. All temperatures are in degrees Celsius. Plant growth forms and surface features are depicted with the following abbreviations-BRYO: bryophyte/moss; DSHR: deciduous shrub; ESHR: evergreen shrub; FORB: forb; GRAM: graminoid; LICH: lichen; LITT: leaf litter; SOIL: bare soil/rock. Note: cover data were not available for all plots. 


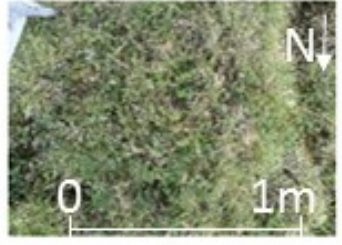

a

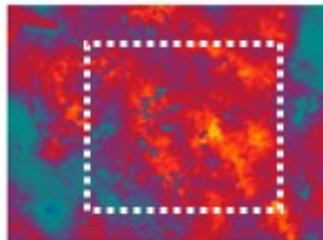

e

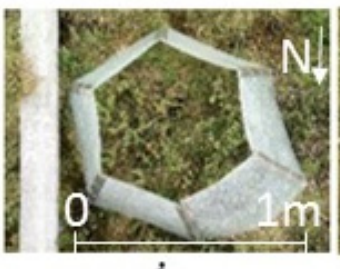

i

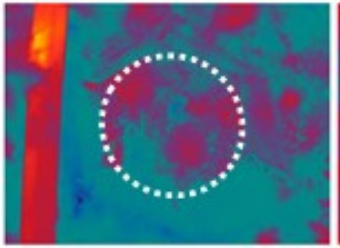

$\mathbf{m}$

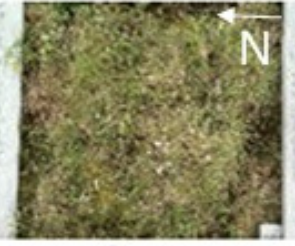

b

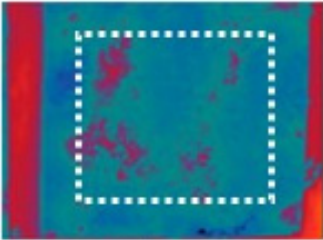

f

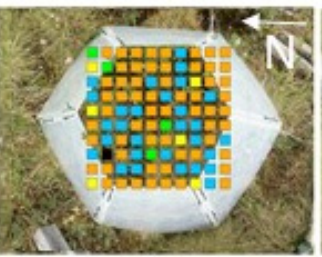

j

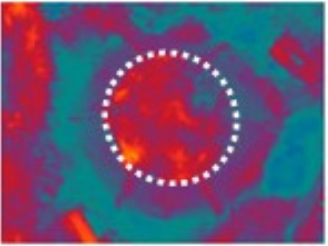

$\mathbf{n}$

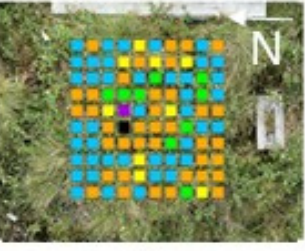

c

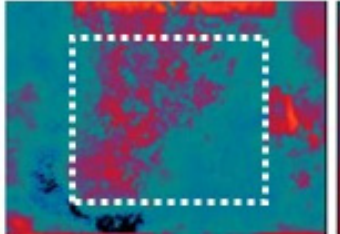

g

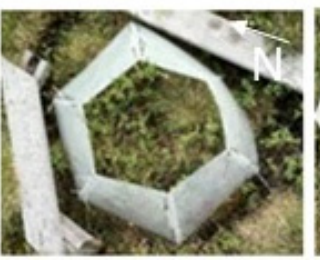

k

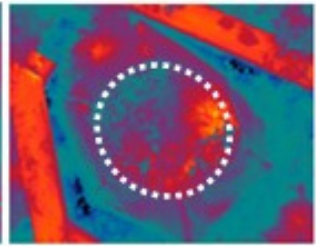

o

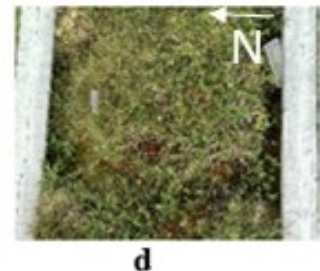

d

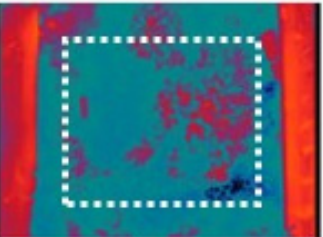

h
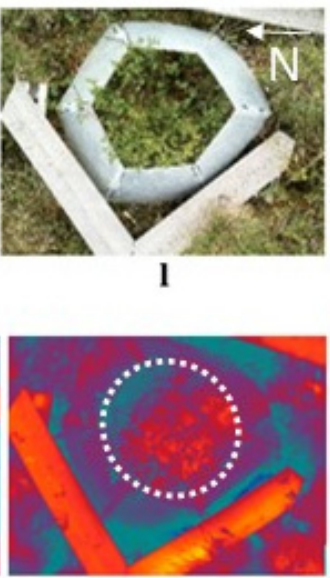

p

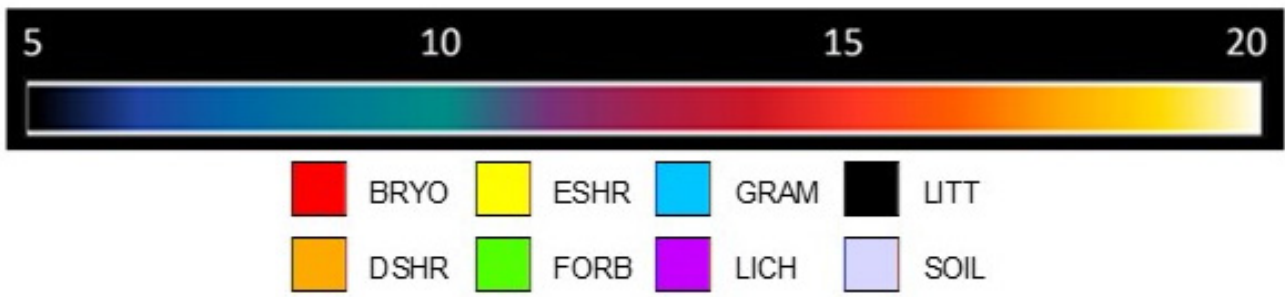

Figure 8. Images depicting four Toolik Lake moist site plots (a-d) and the coinciding thermal images below (e-h); and images of four additional plots (i-1) with coinciding thermal images below ( $\mathbf{m}-\mathbf{p})$. Areas of image analysis are outlined with dotted white lines. All temperatures are in degrees Celsius. Plant growth forms and surface features are depicted with the following abbreviations-BRYO: bryophyte/moss; DSHR: deciduous shrub; ESHR: evergreen shrub; FORB: forb; GRAM: graminoid; LICH: lichen; LITT: leaf litter; SOIL: bare soil/rock. Note: cover data were not available for all plots.

To quantify warming in this study, we subtracted the average surface temperature among all pixels within each control plot (CTL) from all pixels within the coinciding OTC immediately adjacent (Figures 3-8) and as calculated percent difference as follows:

$$
\% \text { Difference }=\frac{|O T C-C T L|}{\left(\frac{O T C+C T L}{2}\right)} \times 100
$$

We present both absolute and percent differences because both approaches have value. However, careful consideration is required when examining percent differences between OTCs and controls due 
to the dependence on the base values involved in the calculation. Therefore, the absolute difference may be most appropriate for this analysis.

\section{Results}

\subsection{Latitudinal Gradient}

The surface temperature for all control and OTC plots averaged across locations and sites were 10.2 and $12.0^{\circ} \mathrm{C}$, respectively, a mean difference of $1.8^{\circ} \mathrm{C}\left(16 \%\right.$ increase, range of $1.27-2.65{ }^{\circ} \mathrm{C}(10 \%-31 \%$ increase). The average surface warming induced by the OTCs was $1.22-3.05{ }^{\circ} \mathrm{C}(9 \%-34 \%$ increase $)$ for all dry plots and $1.31-2.24{ }^{\circ} \mathrm{C}(12 \%-29 \%$ increase) for all wet/moist plots (Figure 9$)$. When the results from both wet and dry plots are combined at each of the three locations, a trend of decreasing warming from High to Low Arctic is noticeable, with the greatest warming at Barrow, intermediate at Atqasuk, and the least warming at Toolik Lake $\left(2.65,1.48\right.$, and $1.27{ }^{\circ} \mathrm{C}$ and $31 \%, 12 \%$, and $10 \%$ difference, respectively, Figure 8). The trend was primarily driven by the dry plots $(3.05,1.70$, and $1.22{ }^{\circ} \mathrm{C}$ and $33 \%, 11 \%$, and $9 \%$ increase for Barrow, Atqasuk, and Toolik Lake, respectively). Among the wet/moist plots, the Atqasuk wet site data showed slightly lower warming than the Toolik Lake moist plots $\left(2.24,1.27\right.$, and $1.31{ }^{\circ} \mathrm{C}$ and $29 \%, 15 \%$, and $12 \%$ increase for Barrow, Atqasuk, and Toolik Lake, respectively).

\subsection{Soil Moisture Effects}

Dry plot surface temperatures were warmer than those of wet/moist plot for both control and OTC plots at all three sites. In fact, on the dates images were taken, surface temperatures for both control and OTC dry plots at Atqasuk surpassed those of dry plots at Toolik Lake, our lowest latitude site. Average, plot-level, surface temperature among dry control plots ranged from a minimum of $5.8^{\circ} \mathrm{C}$ at Barrow (Figures $3 \mathrm{~h}$ and $9 \mathrm{~b}$ ), to a maximum of $15.4^{\circ} \mathrm{C}$ at Atqasuk (Figures $5 \mathrm{f}$ and $10 \mathrm{~b}$ ). Average plot-level surface temperature among dry OTC plots ranged from a minimum of $8.3^{\circ} \mathrm{C}$ at Barrow (Figures $3 \mathrm{~m}$ and $10 \mathrm{~b}$ ) to a maximum of $17.3^{\circ} \mathrm{C}$ at Atqasuk (Figures $5 \mathrm{p}$ and $10 \mathrm{~b}$ ). The average plot surface temperature for all dry controls and OTCs were 11.8 and $13.8^{\circ} \mathrm{C}$, respectively, equaling a total difference among dry plots of $2.0^{\circ} \mathrm{C}(16 \%$ increase, Table S1).

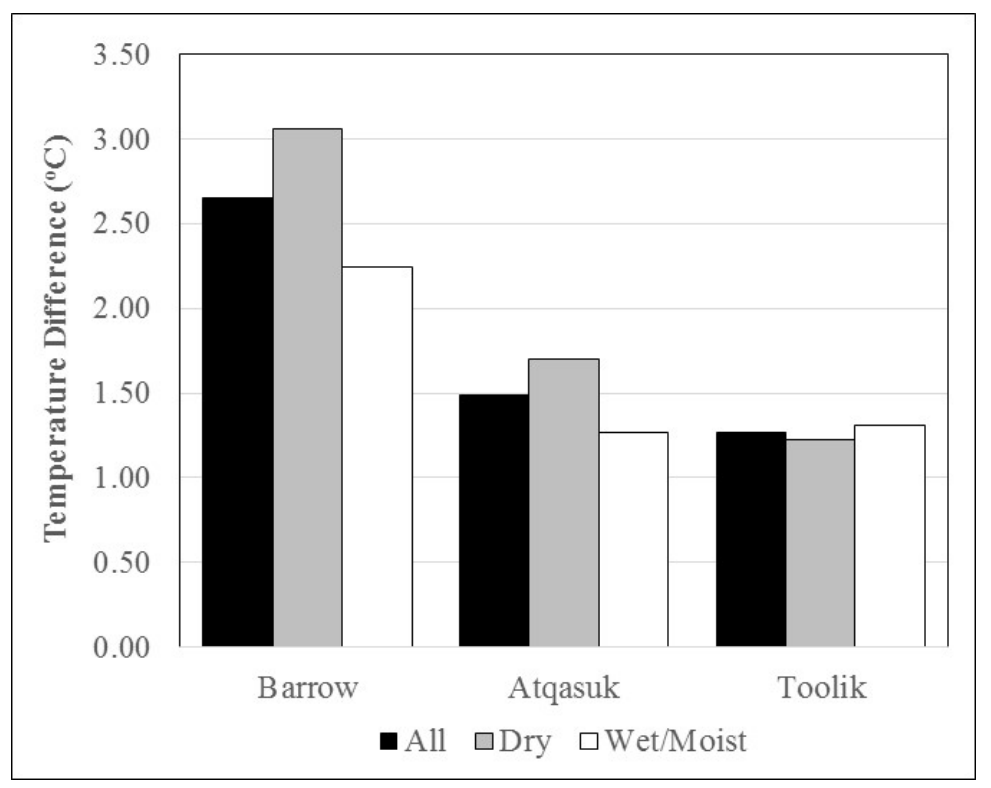

Figure 9. Mean difference between Open Top Chamber (OTC) and control plot surface temperatures (OTC-control). 

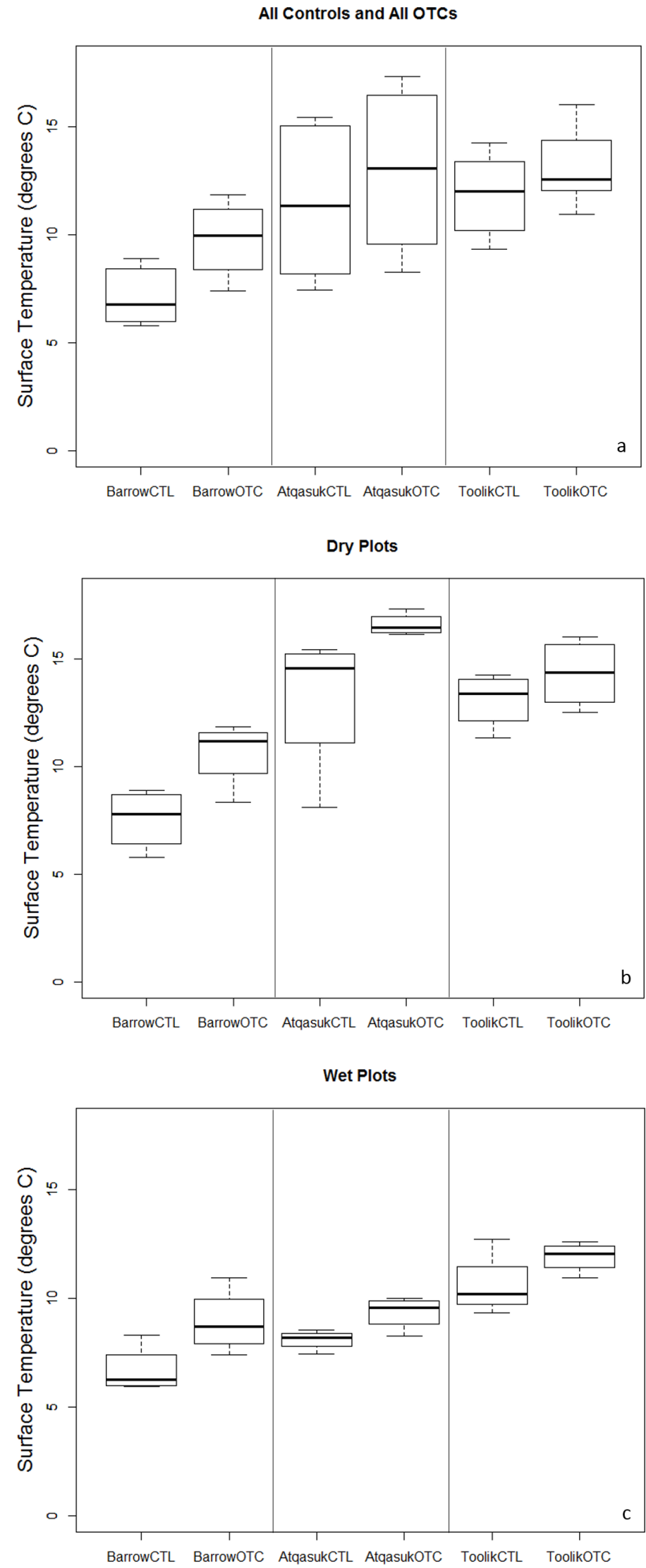

Figure 10. Boxplots of the plot-level average surface temperature data for all controls (CTL) and all Open Top Chambers (OTC) (a); all dry plots (b); and all wet/moist plots (c). 
Average surface temperature of the controls among wet/moist plots ranged from a minimum of $5.9^{\circ} \mathrm{C}$ at Barrow (Figures $4 \mathrm{e}$ and $10 \mathrm{c}$ ) to a maximum of $12.7^{\circ} \mathrm{C}$ at Toolik Lake (Figures $8 \mathrm{e}$ and $10 \mathrm{c}$ ). Average surface temperature within wet/moist OTC plots ranged from a minimum of $7.4{ }^{\circ} \mathrm{C}$ at Barrow (Figures $4 \mathrm{o}$ and $10 \mathrm{c}$ ) to a maximum of $12.6^{\circ} \mathrm{C}$ at Toolik Lake (Figures $8 \mathrm{n}$ and 10c). The average temperature for all wet/moist controls and OTCs were $8.5^{\circ} \mathrm{C}$ and $10.1^{\circ} \mathrm{C}$, respectively, equaling a total difference among wet plots of $1.6{ }^{\circ} \mathrm{C}(17 \%$, Table S2).

The TIR revealed that temperatures are highly variable within the OTCs compared to controls, especially at Barrow. The range of pixel surface temperature values for dry plot controls vs. OTCs were 3-18 ${ }^{\circ} \mathrm{C}$ vs. $3-23{ }^{\circ} \mathrm{C}$, respectively, for Barrow and $9-19{ }^{\circ} \mathrm{C}$ vs. $9-20^{\circ} \mathrm{C}$ for Toolik Lake, respectively (Figure 11). The range of pixel surface temperature values for wet/moist plot controls vs. OTCs were $2-13{ }^{\circ} \mathrm{C}$ vs. $3-22{ }^{\circ} \mathrm{C}$, respectively, for Barrow and $8-19{ }^{\circ} \mathrm{C}$ vs. $9-20^{\circ} \mathrm{C}$ for Toolik Lake, respectively (Figure 11).
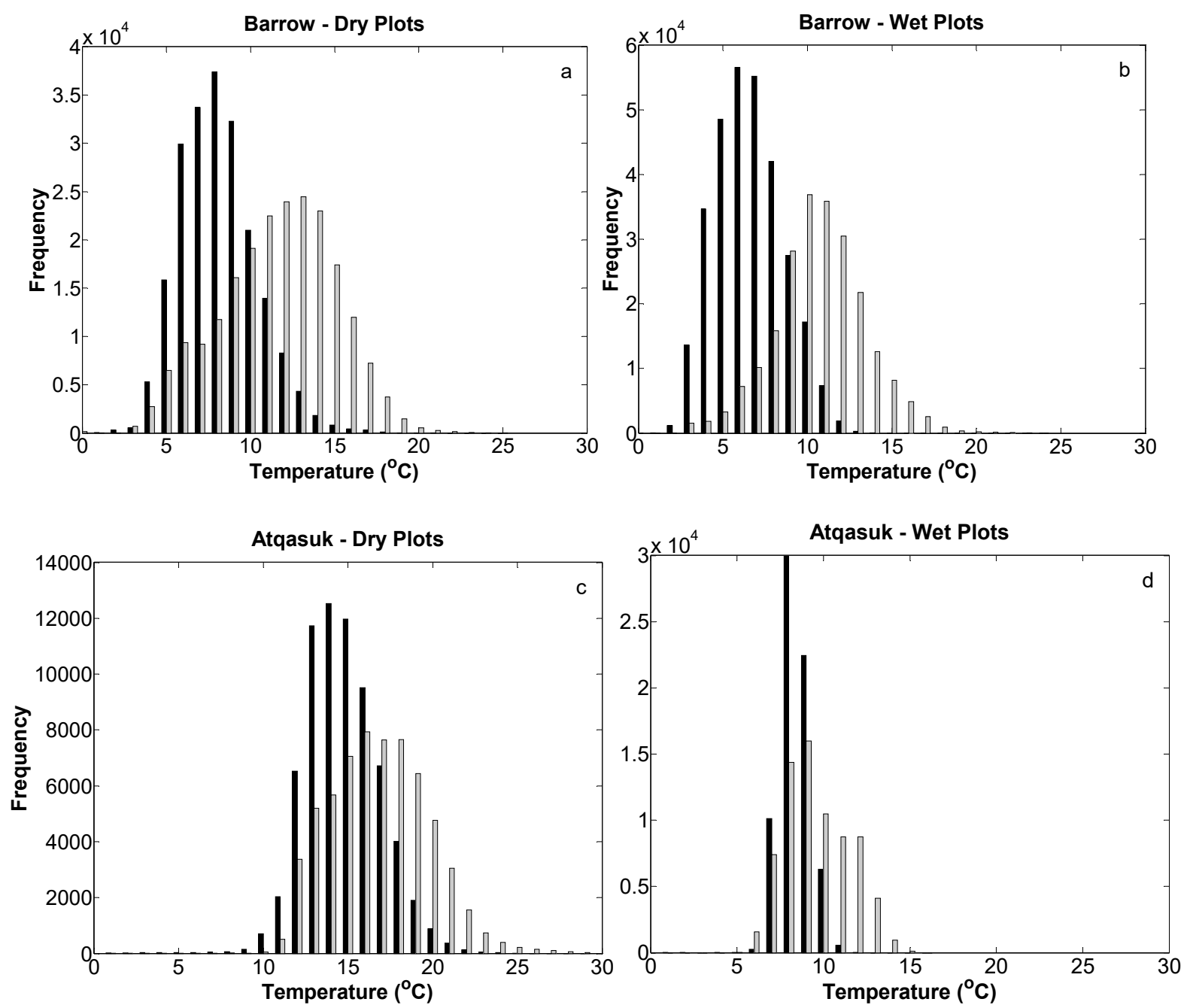

Figure 11. Cont. 

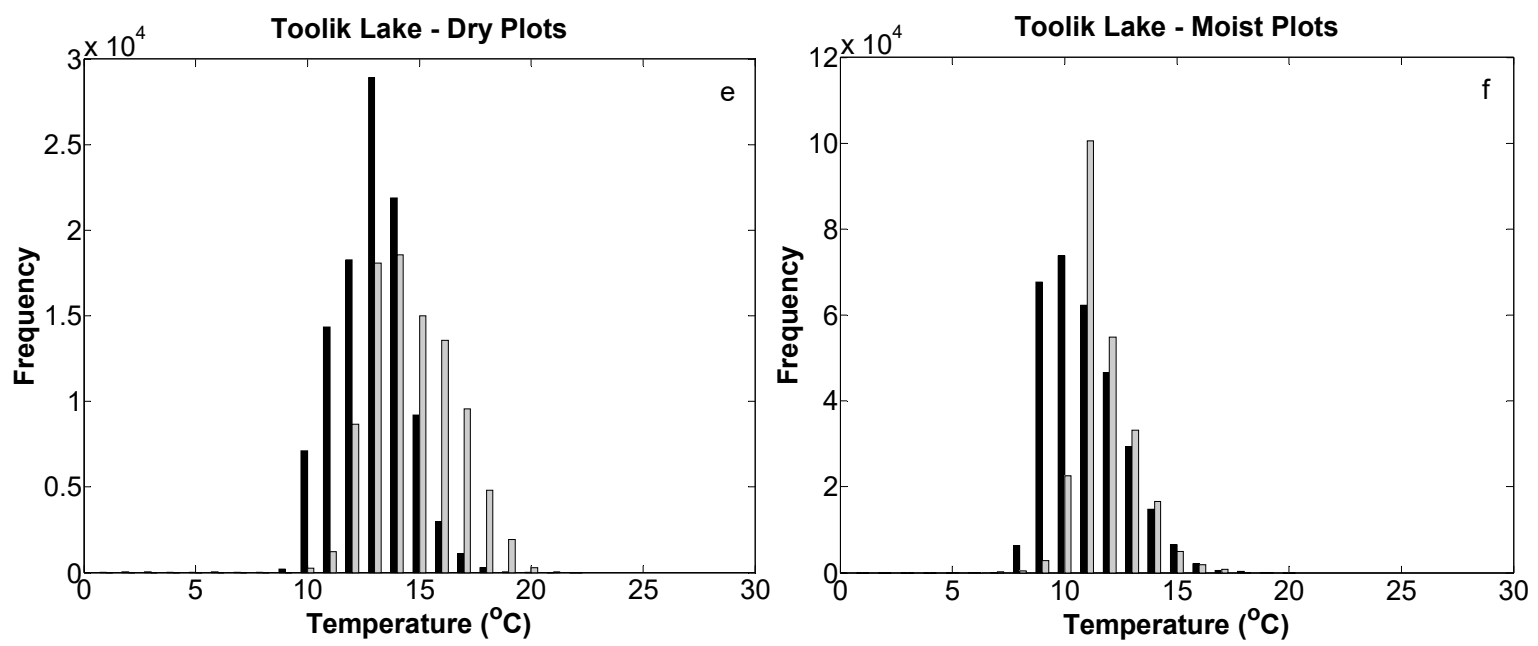

Figure 11. Histograms of pixel temperatures within the OTCs (gray) and the coinciding control plots (black) at each of the three locations. Pixel values for all four plots and each treatment (OTC or control) at Barrow dry (a); Barrow wet (b); Atqasuk dry (c); Atqasuk wet (d); Toolik Lake dry (e); and Toolik Lake moist (f) are presented.

Overall, image analysis of individual pixels in the dry plots shows that the greater abundance of exposed litter and standing dead leaves is associated with buildup of higher temperatures when shielded by the OTCs compared to a more uniform temperature distribution in the control plots (Figures 3, 5 and 7). The highest temperatures within the dry plots coincided with areas where a mixture of dry exposed soil, rocks, lichens, and litter were present. The lowest temperatures coincided with areas covered by live vascular plants such as Luzula, Dryas, and Vaccinium (evergreen shrubs), mosses (bryophytes) were present, and greater shading potentially occurs (Figures 3, 5 and 7).

The highest temperatures within the wet/moist plots were found in areas exhibiting an abundance of standing dead litter among Eriophorum and Carex species (graminoids) at Toolik Lake and Atqasuk (Figures 6 and 8). The lowest temperatures within wet/moist plots occurred where live vascular plants such as Salix, Carex, and Betula species (deciduous shrubs and graminoids), little or no standing dead matter, and a greater abundance of moist moss (bryophytes) is exposed.

\section{Discussion}

\subsection{All Plots}

Comparison of the combination of all wet and all dry plots among our three sites shows that the OTCs increase average surface temperatures by $1.2-3.0^{\circ} \mathrm{C}$ at midday, similar to reported increases in air temperatures $[3,4,18,22]$. Our results showed that the greatest surface temperature difference between OTCs and controls $\left(2.65^{\circ} \mathrm{C}\right.$, or $31 \%$ warmer $)$ was at our highest latitude site at Barrow, $\mathrm{AK}$ and the smallest difference $\left(1.27^{\circ} \mathrm{C}\right.$, or $10 \%$ warmer) at our lowest latitude site at Toolik Lake. While these results represent a midday snapshot at peak growing season, conditions during the measurements were generally representative of the typical weather for these sites for early August. While the finding of a greater proportional temperature difference at high latitude $v$ s. low latitude was also reported in a cross-site comparison [22], absolute temperature difference did not show a clear pattern with latitude in that study. The best predictor of temperature increase in OTCs is irradiance [22,28], which generally decreases with increased latitude. The strongest plant response to OTCs has been reported for low latitude sites [15]. The warming effect tends to increase with wind speed at short time scales and low wind speeds, but not at monthly time scales or high wind speeds [18,22].

The underlying basis for the findings in the present study is likely a combination of the effects of plot surface properties (i.e., vegetation and soil) and climate differences along our site gradient. Plant 
cover generally decreases with increasing latitude such that at high latitudes, bare ground, and rocks comprise an important fraction of the surface. The low albedo of dark soil, rocks, and standing deal litter leads to greater surface temperatures, heat storage, and sensible heat released within the OTC compared to surfaces with greater vegetation. At the same time, surface winds likely increase the difference in temperatures between control plots and the sheltered plots within the OTCs by disrupting the boundary layers on leaf and surface objects within the control plots. For our three locations, the number of windy days is greatest at Barrow and least at Toolik (Hollister and Oberbauer, unpubl. data). At Barrow, in particular, the steady, cold maritime winds from the Beaufort Sea cool any objects above the vegetation boundary layer. The depth of soil thaw may also contribute to surface temperatures. Shallow thaw depths may maintain lower temperatures due to close proximity of frozen soil to the surface. Ping et al. 1998 [29] indicated that the deepest thaw depths in Alaska are generally found at the lowest latitudes and the shallowest thaw depths occur on the Coastal Plain. Thaw depths are in part determined by the soil properties and vegetation type [24]. Moss communities and wet graminoid communities are well known for their ability to maintain shallow thaw depths under peat soils. Generally, however, OTCs have not been documented to increase thaw depth [3]. The lower sun angles at the high latitude location would imply potentially smaller warming effects, but leaves of the dominant vascular plants tend to be near vertical at high latitudes, potentially compensating for low sun angles [30].

For both wet and dry plots, the controls exhibited a narrower range of surface temperatures compared to the distribution of temperatures in the OTCs. In most cases, the effect of the OTCs was to broaden the temperature distribution into higher temperatures compared to controls, rather than a simple shift to higher mean temperature with the same temperature range. Visual inspection of TIR images clearly reveal that these temperature differences were not uniformly distributed. It should be reinforced here that these pixel temperatures are only those from the center portion of the OTC and do not include edge locations near the chamber walls, so the actual temperature ranges in OTCs are likely wider than reported here. Whether this high variance persists for pixel daily averages, at the daily time scale, is uncertain. The surface temperature variability here would predict that measurements of within-plot plant responses should be more variable in OTCs than in controls [22].

\subsection{Soil Moisture Effects}

Dry plot surface temperatures were generally warmer and had greater increases in response to OTCs compared to those in wet/moist plots for Barrow and Atqasuk (Figures 9 and 10). The warmest plots overall were the dry site plots at Atqasuk, a response in part to low cloud cover during image collection. However, the dry site at Atqasuk is also the least vegetated of all the sites with the greatest potential for soil heating. The Atqasuk wet site measured within $2 \mathrm{~h}$ of the dry site on the same day had much lower temperatures and was intermediate in temperatures between those of Barrow and Toolik wet/moist sites. The wet/moist plots at the three locations have essentially no exposed soil and rocks and low diversity of surface features overall compared to the dry sites (Figures 4, 6 and 8). On that basis, wet/moist plots would be expected to have lower ranges of surface temperatures in the OTC compared to those of the dry sites, as was generally found though the temperature range on the Barrow wet sites was quite large. The moist site at Toolik was quite different from the wet sites at Barrow and Atqasuk, with drier soils and higher plant and structural diversity, factors that may have led to the similar degree of warming as that found for the Toolik Lake dry site.

In addition to the vegetation and soil surface effects on surface temperature differences between dry and wet/moist plots discussed previously, these plot types differ strongly in terms of soil depth of thaw and soil moisture. A frequent effect of OTCs is reduced soil moisture [18]. If vascular and poikilohydric plants in dry OTC plots are water limited and evapotranspiration is reduced, the difference in surface temperatures between those in OTCs and controls will be magnified. The dry sites, with primarily mineral soils and sparse vegetation cover, typically have thaw depths well below $1 \mathrm{~m}$ at peak growing season. In contrast, the insulative effects of the organic soils in the wet/moist 
sites result in shallower depths of thaw in the wet/moist sites that maintain lower soil temperatures and the water table closer to the surface. The wet sites of Barrow and Atqasuk frequently have water at or above the soil surface during the growing season. While image analysis shows that vegetation with leaves and/or standing dead matter above the soil/standing water within the plot warm to higher temperatures when shielded by the OTC, the presence of standing water generally lowers the warming effect. Water near the surface, while lowering the albedo, facilitates energy loss by latent rather than sensible heat and surface cooling via evapotranspiration, especially from moist moss surfaces [31]. Water at or near the surface also represents a thermal mass that requires large heat input to increase temperature $[13,18]$.

\section{Conclusions}

This study reports on the use of advanced thermal infrared imagery to analyze the peak growing season temperature patterns within OTCs, the passive warming devices commonly used for simulation of future temperature regimes in Arctic, Antarctic, and alpine communities. We selected long-term monitoring sites spanning latitudinal and moisture gradients where OTCs have been in place every growing season since the mid 1990s. The use of this technology enabled for the first time the quantification of the frequency distribution of surface temperatures within the OTCs and control plots at high spatial resolution. Major findings of our study are: (1) Similar to air temperature modification by OTCs, midday surface temperatures increased by $1-3{ }^{\circ} \mathrm{C}$ on average across all sites; (2) The greatest average surface warming (wet and dry sites combined) occurred at the highest latitude site $\left(2.65^{\circ} \mathrm{C}\right.$ : Barrow, AK) and the lowest average surface warming occurred at our lowest latitude site at $\left(1.27{ }^{\circ} \mathrm{C}\right.$ : Toolik Lake); (3) Surface temperatures were higher and OTCs tended to increase temperatures more at dry sites than wet sites; (4) Surface temperatures within OTCs have much broader temperature distributions then those within control plots. These results imply that plant responses within OTCs should have greater variance than those in control plots.

This study serves as a foundation for future studies examining temperature-related phenomena (such as metabolism, heat stress, water stress, etc.) at finer scales, potentially targeting thermal properties of specific species, rather than just a plot average. Ground-based Light Detection and Ranging (LIDAR), in combination with detailed species abundance, and spatial composition data (i.e., proximity to neighboring plants and height differences among species present) would aid in quantifying the level to which surface structure plays a role in temperature modification to different tundra species at such a fine scale. Other variables to consider for future research are differences in temperature modification due to irradiance level, fraction direct/diffuse, sun angle, and duration of sunlight. Considering image processing techniques, when sites are geographically close, improvements are potentially attainable in similar studies if radiometric temperatures are analyzed which relieves the complications of atmospheric correction and emissivity requirements. Although, the instruments used in this study utilize on-the-fly radiometric calibration with an internal blackbody. Furthermore, the very small distance between our sensor and target reduces the impact of atmospheric effects and potential errors in emissivity assignment become negligible. Becker and Li found that if variation in emissivity and actual temperature within a pixel are small, then the radiometric temperature and the surface temperature are the same [32]. Further research could quantify the magnitude of warming by each species, using radiometric temperatures for validation of results to potentially identify thresholds for survival or mortality throughout different time periods including diurnal, weekly, monthly, and seasonal timescales to investigate potential bias by midday image acquisition times at peak growing season. We foresee future studies expanding these findings to describe species-level thermodynamics that could prove highly valuable toward a better understanding of species-specific responses to changes in Arctic climate conditions.

Acknowledgments: This material is based in part upon work supported by the National Science Foundation under Grant Numbers OPP-0856710, OPP-0856516, PLR-1432982, and PLR-1432277. Any opinions, findings, and conclusions or recommendations expressed in this material are those of the author(s) and do not necessarily 
reflect the views of the National Science Foundation. The authors acknowledge the following for assistance in this research: Timothy Botting, Jeremy May, and Christine Pardo for aid in field data collection, the Toolik Lake Biological Field Station Staff, CH2MHill Polar Services, and UMIAQ Logistics. The authors of this manuscript also graciously acknowledge the independent peer reviewers for improving the quality of this manuscript. Additional support for Nathan C. Healey was carried out at the Jet Propulsion Laboratory, California Institute of Technology, under a contract with the National Aeronautics and Space Administration.

Author Contributions: All authors assisted in the analyzing and editing of the paper. Nathan C. Healey is the main author who processed the data, developed the methodology, analyzed the results, and wrote the manuscript.

Conflicts of Interest: The authors declare no conflicts of interest.

\section{References}

1. Henry, G.H.R.; Molau, U. Tundra plants and climate change: The International Tundra Experiment (ITEX). Glob. Chang. Biol. 1997, 3, 1-9. [CrossRef]

2. Arft, A.M.; Walker, M.D.; Gurevitch, J.; Alatalo, J.M.; Bret-Harte, M.S.; Dale, M.; Diemer, M.; Gugerli, F.; Henry, H.R.; Jones, M.H.; et al. Responses of tundra plants to experimental warming: Meta-analysis of the international tundra experiment. Ecol. Monogr. 1999, 69, 491-511. [CrossRef]

3. Hollister, R.D.; Webber, P.J. Biotic validation of small open-top chambers in a tundra ecosystem. Glob. Chang. Biol. 2000, 6, 835-842. [CrossRef]

4. Hollister, R.D.; Webber, P.J.; Tweedie, C.E. The response of Alaskan Arctic tundra to experimental warming: Differences between short- and long-term responses. Glob. Chang. Biol. 2005, 11, 525-536. [CrossRef]

5. De Frenne, P.; de Schrijver, A.; Graae, B.J.; Gruwez, R.; Tack, W.; Vandelook, F.; Hermy, M.; Verheyen, K. The use of open-top chambers in forests for evaluating warming effects on herbaceous understory plants. Ecol. Res. 2010, 25, 163-171. [CrossRef]

6. De Frenne, P.; Brunet, J.; Shevtsova, A.; Kolb, A.; Graae, B.J.; Chabrerie, O.; Cousins, S.A.; Decocq, G.; de Schrijver, A.; Diekmann, M.; et al. Temperature effects on forest herbs assessed by warming and transplant experiments along a latitudinal gradient. Glob. Chang. Biol. 2011, 17, 3240-3253. [CrossRef]

7. Oberbauer, S.F.; Elmendorf, S.C.; Troxler, T.G.; Hollister, R.D.; Rocha, A.V.; Bret-Harte, M.S.; Dawes, M.A.; Fosaa, A.M.; Henry, G.H.R.; Høye, T.T.; et al. Phenological response of tundra plants to background climate variation tested using the International Tundra Experiment. Philos. Trans. R. Soc. B 2013, 368, 20120481. [CrossRef] [PubMed]

8. Jones, M.H.; Bay, C.; Nordenhäll, U. Effects of experimental warming on Arctic willows (Salix spp.): A comparison of responses from the Canadian High Arctic Alaskan Arctic and Swedish Subarctic. Glob. Chang. Biol. 1997, 3, 55-60. [CrossRef]

9. Johnson, D.; Campbell, C.D.; Lee, J.A.; Callaghan, T.V.; Gwynn-Jones, D. Arctic microorganisms respond more to elevated UV-B radiation than $\mathrm{CO}_{2}$. Nature 2002, 416, 82-83. [CrossRef] [PubMed]

10. Totland, Ø.; Alatalo, J.M. Effects of temperature and date of snowmelt on growth reproduction and flowering phenology in the arctic/alpine herb Ranunculus glacialis. Oecologia 2002, 133, 168-175. [CrossRef]

11. Walker, M.D.; Walker, D.A.; Welker, J.M.; Arft, A.M.; Bardsley, T.; Brooks, P.D.; Fahnestock, T.; Jones, M.H.; Losleben, M.; Parsons, A.N.; et al. Long-term experimental manipulation of winter snow regime and summer temperature in Arctic and alpine tundra. Hydrol. Process. 1999, 13, 2315-2330. [CrossRef]

12. Jones, M.H.; Fahnestock, J.T.; Walker, D.A.; Walker, M.D.; Welker, J.M. Carbon dioxide fluxes in moist and dry Arctic tundra during the snow-free season: Responses to increases in summer temperature and winter snow accumulation. Arct. Alp. Res. 1998, 30, 373-380. [CrossRef]

13. Oberbauer, S.F.; Tweedie, C.E.; Welker, J.M.; Fahnestock, J.T.; Henry, G.H.R.; Webber, P.J.; Hollister, R.D.; Walker, M.D.; Kuchy, A.; Elmore, E.; et al. Tundra $\mathrm{CO}_{2}$ fluxes in response to experimental warming across latitudinal and moisture gradients. Ecol. Monogr. 2007, 77, 221-238. [CrossRef]

14. Walker, M.D.; Wahren, C.H.; Hollister, R.D.; Henry, G.H.R.; Ahlquist, L.E.; Alatalo, J.M.; Bret-Harte, M.S.; Calef, M.P.; Callaghan, T.V.; Carroll, A.B.; et al. Plant community responses to experimental warming across the tundra biome. Proc. Natl. Acad. Sci. USA 2006, 103, 1342-1346. [CrossRef] [PubMed]

15. Elmendorf, S.C.; Henry, G.H.R.; Hollister, R.D.; Bjórk, R.G.; Bjorkman, A.D.; Callaghan, T.V.; Collier, L.S.; Cooper, E.J.; Cornelissen, J.H.C.; Day, T.A.; et al. Global assessment of experimental climate warming on tundra vegetation: Heterogeneity over space and time. Ecol. Lett. 2012, 15, 164-175. [CrossRef] [PubMed] 
16. Webber, P.J.; Walker, M.D. The International Tundra Experiment (ITEX): Resolution. Arct. Alp. Res. 1991, 23, 124 .

17. Brown, J.; Böcher, J.; Desforges, M.N.; Edlund, S.; Henry, G.H.R.; Johnstone, J.; Jones, G.A.; Lévesque, E.; Lewkowicz, T.; Marion, G.M.; et al. International Tundra Experiment Manual, 2nd ed.; Molau, U., Mølgaard, P., Eds.; Danish Polar Centre: Copenhagen, Denmark, 1996.

18. Marion, G.M.; Henry, G.H.R.; Freckman, D.W.; Johnstone, J.; Jones, G.; Jones, M.H.; Lévesque, E.; Molau, U.; Mølgaard, P.; Parsons, A.N.; et al. Open-top designs for manipulating field temperature in high-latitude ecosystems. Glob. Chang. Biol. 1997, 3, 20-32. [CrossRef]

19. Welker, J.M.; Fahnestock, J.T.; Henry, G.H.R.; O'Dea, K.W.; Chimner, R.A. $\mathrm{CO}_{2}$ exchange in three Canadian high arctic ecosystems: Response to long-term experimental warming. Glob. Chang. Biol. 2004, 10, 1981-1995. [CrossRef]

20. Jónsdóttir, I.S.; Magnusson, B.; Gudmundsson, J.; Elmarsdottir, A.; Hjartarson, H. Variable sensitivity of plant communities in Iceland to experimental warming. Glob. Chang. Biol. 2005, 11, 553-563. [CrossRef]

21. Wahren, C.H.A.; Walker, M.D.; Bret-Harte, M.S. Vegetation responses in Alaskan Arctic tundra after 8 years of a summer warming and winter snow manipulation experiment. Glob. Chang. Biol. 2005, 11, 537-552. [CrossRef]

22. Bokhorst, S.; Huiskes, A.; Aerts, R.; Convey, P.; Cooper, E.J.; Dalen, L.; Erschbamer, B.; Gudmundsson, J.; Hofgaard, A.; Hollister, R.D.; et al. Variable temperature effects of Open Top Chambers at polar and alpine sites explained by irradiance and snow depth. Glob. Chang. Biol. 2013, 19, 64-74. [CrossRef] [PubMed]

23. Chivers, M.R.; Turetsky, M.R.; Waddington, J.M.; Harden, J.W.; McGuire, A.D. Effects of experimental water table and temperature manipulations on ecosystem $\mathrm{CO}_{2}$ fluxes in an Alaskan rich fen. Ecosystems 2009, 12, 1329-1342. [CrossRef]

24. Hollister, R.D.; Webber, P.J.; Nelson, F.E.; Tweedie, C.E. Soil thaw and temperature response to air warming varies by plant community: Results from an open-top chamber experiment in northern Alaska. Arct. Antarct. Alp. Res. 2006, 38, 206-215. [CrossRef]

25. ACADIS Gateway: An Arctic Data Repository. Available online: http://www.aoncadis.org/projects (accessed at 25 July 2015).

26. Healey, N.C.; Oberbauer, S.F.; Ahrends, H.E.; Dierick, D.; Welker, J.M.; Leffler, A.J.; Hollister, R.D.; Vargas, S.A.; Tweedie, C.E. A mobile instrumented sensor platform for long-term terrestrial ecosystem analysis: An example application in an Arctic tundra ecosystem. J. Environ. Inform. 2014, 24, 1-10. [CrossRef]

27. Wilber, A.C.; Kratz, D.P.; Gupta, S.K. Surface Emissivity Maps for Use in Satellite Retrievals of Longwave Radiation; National Aeronautics and Space Administration, Langley Research Center: Hampton, VA, USA, 1999; pp. 1-31.

28. De Boeck, H.J.; de Groote, T.; Nijs, I. Leaf temperatures in glasshouses and opentop chambers. New Phytol. 2012, 194, 1155-1164. [CrossRef] [PubMed]

29. Ping, C.L.; Bockheim, J.G.; Kimble, J.M.; Michaelson, G.J.; Walker, D.A. Characteristics of cryogenic soils along a latitudinal transect in Arctic Alaska. J. Geophys. Res. 1998, 103, 28917-28928. [CrossRef]

30. Miller, P.C.; Stoner, W.A.; Tieszen, L.L. A model of stand photosynthesis for the wet meadow tundra at Barrow, Alaska. Ecology 1976, 57, 411-430. [CrossRef]

31. Beringer, J.; Lynch, A.H.; Chapin, F.S., III; Mack, M.; Bonan, G.B. The representation of Arctic soils in the land surface model: The importance of mosses. J. Clim. 2001, 14, 3324-3335. [CrossRef]

32. Becker, F.; Li, Z.-L. Surface temperature and emissivity at various scales: Definition, measurement, and related problems. Remote Sens. Rev. 1995, 12, 225-253. [CrossRef]

(C) 2016 by the authors; licensee MDPI, Basel, Switzerland. This article is an open access article distributed under the terms and conditions of the Creative Commons by Attribution (CC-BY) license (http:/ / creativecommons.org/licenses/by/4.0/). 